\title{
Facilitators and barriers to expansion of newborn screening programs in the $21^{\text {st }}$ century
}

\section{Authors:}

\section{Kee Chan, PhD}

Clinical Assistant Professor, University of Illinois at Chicago, School of Public Health, Chicago, IL. 60612 USA (E-mail: kchan88@uic.edu)

\section{Michael Petros, DrPH}

Clinical Assistant Professor, University of Illinois at Chicago, School of Public Health, Chicago, IL. 60612 USA (E-mail: mpetro6@uic.edu)

\section{Correspondence address:}

Kee Chan, $\mathrm{PhD}$

Clinical Assistant Professor

University of Illinois at Chicago

School of Public Health - Division of Health Policy and Administration 1603 West Taylor Street

MC 923, Room 753

Chicago, IL. 60612 USA

Tel: 1-312- 996-1325

E-mail: kchan88@uic.edu

\section{Word Count: 2,846;}

\section{Tables: 5; Figures: 1}

Disclosure: The authors declare that there are no conflicts of interest. The authors acknowledge equal responsibility for the content. There is no applicable funding disclosure. Neither human subjects nor data from human subjects were utilized in this project.

\begin{abstract}
Background - Newborn screening programs have grown over the past 50 years to include screening for more than 40 metabolic and genetic disorders. Technology, or the ability to screen for disorders, is not the sole influence for expansion of screening. The lack of clarity in how facilitators and barriers impact newborn screening programs can affect the stakeholder's perspective of public health department initiatives and future goals. While it is important to detect diseases early to optimize the benefits of timely treatment, the process of newborn screening is a complex, multi-level, interrelated decision-making entity.
\end{abstract}

Method - A logic model was developed in order to help stakeholders establish reasonable expectations, while being aware of the delays and unanticipated consequences which might occur when attempting to expand newborn screening programs.

Results and Conclusions - The logic model emphasizes that expansion of newborn screening relies on several interrelated factors that can be identified as Technical, Financial, Policy and Human Capital. Further delineating these factors into a series of checklists promises to be of value to decision-makers in state-operated newborn screening programs, given conditions of constrained resources and anticipated barriers.

Key Words: newborn screening; candidate disorders; expansion policy; decision framework; logic model 


\section{Introduction and Background}

It is appropriate, after the first onehalf century of initiation of Newborn Screening (NBS) in the United States, that an examination be made of the factors that helped NBS expand to today's levels, and of potential barriers to future expansion.

\subsection{Technology improvement:}

\section{Tandem Mass Spectrometry (MS/MS)}

The growth of NBS over the past fifteen years has been driven by advances in technology, particularly the introduction of tandem mass spectrometry (MS/MS) in the late 1990's ${ }^{1}$. With the introduction of reliable high-throughput assays, the addition of disorders to NBS panels has proceeded at a rapid pace ${ }^{2}$. Chace provides a historical perspective concerning MS/MS and the increasing potential for MS/MS use in newborn screening ${ }^{3}$. However, the ability to expand NBS has raised a number of questions, particularly regarding whether or not to adhere to the classic screening criteria of Wilson-Jungner when adding conditions to the panel ${ }^{4}$. Ethical and legal issues are present due to the nature of mass screening of minors without consent under the states' public health authority ${ }^{5,6}$.

NBS is typically managed as a function of state health departments which are subject to the same processes, limitations, finances and political support as other entities of government. Candidate disorders, i.e., disorders under consideration for inclusion in newborn screening, have been proposed at the state /local level mainly based on clinical aspects of detection, identification and treatment, with at times, only marginal consideration of the impact such expansion would have on the public health infrastructure. Adding conditions due to political reasons has occurred.

It is with this in mind that this decision framework of facilitators and potential barriers to expansion of NBS is presented so that all interested parties, particularly legislators, parents and advocacy groups, understand the processes involved for expanding state public health services. 


\subsection{Expansion: Severe Combined} Immunodeficiency (SCID) and the Lysosomal Storage Diseases (LSDs)

Once MS/MS was demonstrated to be a viable platform for multiplex testing of dried blood spots, investigators began searching for candidate disorders beyond amino acid, organic acid, and fatty acid oxidation disorders, which up to that point had been the mainstay of MS/MS ${ }^{7}$.

For example, the development of the TREC-assay by Chan and Puck clearly showed the way forward for universal screening for Severe Combined Immunodeficiency (SCID) and other primary immunodeficiencies ${ }^{8,9}$.

Following New York State's implementation of screening for Krabbe Disease in 2006, states such as Illinois, Missouri and New Mexico moved forward and passed legislation adding various Lysosomal Storage Diseases (LSDs) to their respective panels ${ }^{10,11,12}$. These LSDs include, Fabry Disease, Gaucher Disease, Hunter's Disease, Hurler's Disease,
Krabbe Disease, Niemann-Pick Type A/B and Pompe Disease.

It was realized that a number of these disorders were uncharacterized as far as natural history and a number had no defined treatment. Taking into account the nature of NBS being performed without consent in the majority of states, this reopened a debate about the application of the Wilson-Jungner criteria to mandatory public health screening programs identifying children with inborn errors of metabolism that have no established treatment or intervention $4,6,13$.

\subsection{Issues beyond the screening} technology

NBS has reached the juncture where the questions go beyond the basic "Can the NBS lab perform test ' $\mathrm{X}$ ' using DBS?' Decisions based on the perspectives of key players in the process including, Laboratory, Case Follow-up/Management, Public Health Administrators, Clinical Specialists, Ethicists, Parents and Advocacy Groups have become more complex. The positions of these groups can 
come into conflict. As an example, a number of the aforementioned LSDs were reviewed by the Secretary's Advisory Committee on Heritable Disorders in Newborns and Children (SACHDNC; now named the Discretionary Advisory Committee on Heritable Disorders in Newborns and Children) and were found to be not appropriate candidates for NBS panels at that time ${ }^{14}$.

Clearly, this is a complex process with many focal points of facilitation or limitation.

Parents of children affected by inherited disorders play an important role when additional disorders are under consideration for incorporation into NBS panels. The perspective parents bring to the table is unique in that they (and other family members) may have experienced first-hand the effects that an inborn error of metabolism has on the child and family. In a number of states, parents are represented on the respective NBS advisory committees ${ }^{15}$. The activities of parents and advocacy groups have become more complex and many establish an alignment, temporary or permanent, with other influential parties.

While there are important differences between states, the process for changing public health policy may be driven by the actions of advocates and stakeholders, external to core public health practitioners. The Hunter's Hope Foundation of New York was instrumental in adding Krabbe disease to the New York State (NYS) NBS panel ${ }^{16}$. Similarly in Illinois, the proactive efforts of the Evanosky Foundation and the March of Dimes ${ }^{\circledR}$ were instrumental in Krabbe disease and four other LSDs being added to the Illinois NBS panel ${ }^{17}$.

Conflicting issues may be resolved through negotiation and discussion, although these issues tend to be operational in nature. For example: 1). Organizing the participants for pilot studies; 2). Obtaining consent for the pilot testing at the birthing hospitals, rather than at the public health agency; 3). Forwarding the request for fee increase through the agency legal department and then a 
committee on administrative rules. Policy issues tend to be processed at high levels of the agency as a consequence of the political side of public health. The proposed panel of additional disorders may subsequently remain unchanged, although the timeline for implementation by the agency could be somewhat flexible.

Newborns diagnosed with genetic disorders require a multidisciplinary approach to manage the complex therapies they will require over time. Specialist care providers must be available to all newborns receiving positive screenings. Advocates such as consumer representatives and other experts in the field play important roles in decision making regarding implementation of new technologies. Human capital inputs give NBS credibility and lead to a general appreciation of a public system that invites and respects consumer input and also optimizes care for newborns.

\section{Genetic health service research} efforts have been small compared to similar disciplines because many (i.e., genetic health service research efforts) remain in the developmental stage and the prevalence of disorders is low. There may be regional differences in provision of services across the US and a mismatch between technological advances and clinical genetic services, including lack of effective treatments for some disorders and resources for disease management and follow-up services. NBS program funding should be adequate for complete screening, diagnosis, and followup, and should also be available for quality assurance data collection and ongoing program evaluation. Although NBS is mandated in every state, financing NBS and other public health programs depend on individual state policies, and programs use varying amounts of federal funding to augment legislative appropriations and fees. NBS may not be funded by general revenues, but rather, specific fees are instituted as the primary source of funding ${ }^{18,19}$.

In 2003, the US Congress chartered the Secretary's Advisory Committee on 
Heritable Disorders in Newborns and Children (SACHDNC) to make screening recommendations. This body then determines which of those disorders are to be included in the Recommended Uniform Screening Panel (RUSP).

The SACHDNC has reviewed nominations for inclusion in the RUSP and has made determinations for several conditions. The status of these determinations is available at: http://www.hrsa.gov/advisorycommittees/ mchbadvisory/heritabledisorders/meetings/ $\underline{\text { index.html) }}{ }^{14}$.

\section{Methods and Approaches}

\subsection{Use of a logic model}

A logic model depicting the potential impact of introducing new diseases and metabolic disorders to the newborn screening panel would provide policy makers insight into the expanded “screening system". Logic models narratively or graphically describe a sequence of cause and effect relationships by illustrating the logical linkages among program inputs, activities, outputs, and outcomes in the short, intermediate, and long term. It is common to apply a systematic matrix to internal and external barriers and facilitator prior to and postimplementation of a program. While there are many different program evaluation tools, the direct objective approach of a logic model provides decision-makers with a clear outline of the key parameters. The logic model framework can help program planners, implementers, and policy makers better understand the resources and cooperative efforts necessary to minimize potential harm and maximize the benefits of expanded newborn screening. To illustrate that it can be applicable to any state-wide program considering newborn screening, the logic model provided proposes key questions and possible outcomes for consideration. If programs are able to successfully address these questions, it may warrant continuing to the next levels; on the other hand, if there are questions that require further analysis and additional resources, reevaluation may be required before moving forward. 


\subsection{Resources critical to the} decision

Here, resources such as financial, human capital, technical, and policy are characterized. After careful review of the literature, four important and relevant factors in implementation and sustainability of screening were identified. Using the logic model provided (Table 1), decision-makers can consider the following questions for each category of resources and determine whether further resources are needed before proceeding to the next parameter, activities. In general, newborn screening programs take into account not only screening, but also downstream activities such as short-term and long-term follow-up, medical management of care, and treatment protocols. While the state-operated Newborn Screening program is primarily responsible for the laboratory screening test, the program implementers must also consider these contingent components farther downstream. In some cases, states (or the responsible public health agency) may opt to contract-out laboratory and/or follow-up services.

\subsection{Dissemination and Validation}

\section{Using Logic Models}

The application of logic models, as described in the Kellogg logic model guide, have been widely used in public health because these models are not only valuable for critical programming but are also indispensable for identifying areas for improvement, disseminating the impact(s), and validating the efficiency and effectiveness of processes and outcomes ${ }^{20}$. According to the Kellogg Logic Model Guide, "The purpose of a logic model is to provide stakeholders with a road map describing the sequence of related events connecting the need for the planned program with the program's desired results. Mapping a proposed program helps you visualize and understand how human and financial investments can contribute to achieving your intended program goals and can lead to program improvement." 20

For instance, the logic model can be created prior to the final determination of 
the program's reach and responsibilities, and can then be used to validate whether the improvement plan utilizes the resources to address the activity and to achieve the projected outcomes. If the desired outcomes were not achieved, the question remains whether there was a gap in the process or whether the outcomes were not appropriate or achievable using the process proposed in the model. A newborn screening logic model is one example of many such recognized logic model applications such as (the logic model to) "Improve Developmental and Social Emotional Screening and Referral Rates of All Children Birth to Age Five" or as the "National Comprehensive Cancer Control Program Logic Model” 21, 22. By using the framework of a logic model and comparing the model(s) to similar programs based on their process or outcomes, an evaluation can be used to validate the proposed program plan.

\section{Recommendations}

When considering the complex decision of implementing a new screening test, it is essential to prioritize the resources needed to successfully identify presumptive cases and care for the affected patients. Most of the time, the downstream components and other screening dimensions such as follow-up and treatment are not initially seen as a part of the 'screening questions'. Parent advocates and other stakeholders, may become frustrated when they become aware of the existence of a screening test that has not been implemented by the state agencybased program. As the logic model illustrates, outcomes are often highly dependent on available resources. Therefore, it is potentially short-sighted to widely promote implementation before appreciating the complexities and understanding the key components in the decision-making process.

\subsection{Resources}

Adequate financial resources are critical to implementing new screening technology (activity) with high sensitivity and specificity (outputs) for appropriate normal and abnormal ranges (outcomes). 
Only then can one justify the allocation of public funds to support public interest (impact).

Personnel supported by resources (human capital) to properly carry out screening efforts (activities) are critical in order to provide timely processing of primary and secondary screening (output) in order to identity cases and resample probable cases (outcomes). Adequate personnel are critical for identifying potential cases, so prompt diagnosis and treatment can be administered (impact).

Technical resources, either developed in-house or utilizing commercially available kits, that can provide rapid turn-around time, feature low error rate, and minimal resampling (activities), must yield high quality sample results (output) so that the public health program can maximize funds to support better health (outcomes).

Every institution must have policy resources that can support the procedures, recommendations, and processes that facilitate (activity) expedited screening (output) with low error and high sensitivity (outcome) so that all screening tests can be accurately evaluated.

\subsection{Systems}

Based on the literature review, there are three major sub-systems at work during process of expanding NBS panel that make up the "functional system" (Figure 1). These sub-systems include:

- The Legislative Influences - the sub-system that determines the laws, regulations and administrative rules governing the delivery of NBS services. The legislature contains the upper and lower houses as well as the various committees and subcommittees, such as the public health committee, where testimony and discussion of proposed legislation occurs. An adjunct component may be an "Administrative Rules Committee", typically a group of appointed legislators who recommend changes to the administrative rules that govern state agencies. For example, the 
committee may approve a proposal to raise the fishing license fee to cover costs of watershed area management. Rules governing fees, testing panels and follow-up of NBS programs may be proposed in a similar manner.

- External influences - the subsystem where forces outside government-based public health operate. These forces often act in the form of interest groups and coalitions that usher a specific agenda to a legislative sponsor or to the Executive branch of government (Governor, Commissioner, Director, Agency Head etc.). For example, advocates and stakeholders may form coalitions with representatives of the pharmaceutical or biotechnology. Another example is parent support groups, including both national organizations and local chapters.

- The Policy Circle - the day-to-day workings of the Executive branch of state government. Specific policies not requiring legislative approval or oversight are implemented by agency directors and other political appointees to carry-out directives from the governor. Agencies of the Executive branch have internal processes for implementing policy, and in some cases, must seek legislative branch approval for budgetary support and appropriation resources.

Using the logic model, recommendations are presented for resource considerations which include: screening, post-screening follow-up, medical management and treatment. For simplicity, the logic model focused on the resource aspects of screening test adoption. Each of these categories classify key decision questions by type, including technical, human capital, policy and financial.

Tables 2 through 5 provide checklists that can guide decision-makers 
as resources necessary for expansion are evaluated.

\section{Public Health Practice}

\section{Implications and Recommendations}

While it is important to detect diseases early to optimize the benefits of timely treatment, the process of newborn screening is a complex, multi-level, interrelated decision-making entity. This paper elucidates these layers by illustrating influential players from the initiative stages to implementation.

Recommendations for screening made by the SACHDNC are important considerations; Kemper et al (2013) introduced a decision matrix to be employed by SACHDNC that incorporates a feasibility and readiness assessment ${ }^{23}$. In reality, it is understandable that an individual state in the U.S. will have its own approach in determining the system, process, and resources for implementation. However, under the current economy, many states are challenged with balancing budget constraints and appropriating limited resources, with meeting the needs and demands of serving the maternal and child health community. With a transparent process or common structure of decision-making, stakeholders at all levels can understand and then appreciate the invisible forces of politics, and other crucial factors that play significant, dynamic roles in the implementation of screening. Here key resources are systematically depicted, leading to optimal output for maximal impact. A unified framework for decision-making enhances the case for achieving the outcome of healthy babies from appropriate early screening. The checklist(s) presented here are a structured guide to inform the readiness of a program considering screening for new disease(s).

Given the international aspects of newborn screening, there are specific details, relative to each public health department or agency that will differ from other similar programs; however, the general overall framework presented in this paper focuses on common resources 
and fundamental mechanisms such as screening, follow-up, diagnosis, management, and education. Checklist(s) and logic models can and should be modified and adapted to specific screening programs. This logic model and related checklists present a timely and informative method to minimize barriers and facilitate discussion among decision-makers and stakeholders to maximize the benefits of newborn screening. 


\section{References}

1. MMWR, "Using Tandem Mass Spectrometry for Metabolic Disease Screening Among Newborns: A Report of a Work Group", April 13, 2001 / Vol. 50 / No. RR-3.

2. National Newborn Screening Resource Center (NNSRC), http://genes-rs.uthscsa.edu

3. Chace DH. Mass Spectrometry in Newborn and Metabolic Screening: Historical Perspective and Future Directions. Journal of Mass Spectrometry, Vol. 44, 163-170, 2009.

4. Petros MP. Revisiting the WilsonJungner criteria: How can supplemental criteria guide public health in the era of genetic screening? Genetics in Medicine, 7-Oct-11, DOI: 10.1097/GIM.0b013e31823331d0 (epublished ahead of print).

5. Ross LF. Newborn screening for lysosomal storage diseases: an ethical and policy analysis. $J$ Inherit Metab Dis. 2012 Jul;35(4):627-34. doi: 10.1007/s10545-011-9435-0. Epub 2011 Dec 22.

6. Ross LF, Saal HM, David KL, Anderson RR; American Academy of Pediatrics; American College of
Medical Genetics and Genomics. Technical report: Ethical and policy issues in genetic testing and screening of children. Genetics in Medicine, 2013 Mar;15(3):234-45. doi: 10.1038/gim.2012.176. Epub 2013 Feb 21.

7. Levy HL. Newborn Screening by Tandem Mass Spectrometry: A New Era. Clinical Chemistry, 44, No. 12, 1998, 2401-2402

8. Chan K, Puck JM. Development of population-based newborn screening for severe combined immunodeficiency. Journal of Allergy and Clinical Immunology, 2005, 115(2), 391-398.

9. Secretary's Advisory Committee on Heritable Disorders in Newborns and Children. Committee Report. 2011 Annual Report to Congress.

10. Illinois Senate Bill 1566, signed into law November 2007, Revised 2011.

11. Missouri House Bill 716, signed into law July 2009.

12. New Mexico House Bill 201, signed into law March 2010. 
13. Hasegawa LE, Fergus KA, Ojeda N, Au SM. Parental attitudes toward ethical and social issues surrounding the expansion of newborn screening using new technologies. Public Health Genomics. 2011;14(4-5):298-306. doi: 10.1159/000314644. Epub 2010 Jul 30.

14. http://www.hrsa.gov/advisorycommitte es/mchbadvisory/heritabledisorders/no $\underline{\text { minatecondition/workgroup.html }}$

15. Hiller EH, Landenburger G, Natowicz MR. Public participation in medical policy-making and the status of consumer autonomy: the example of newborn-screening programs in the United States. Am J Public Health. 1997 Aug;87(8):1280-8.

16. Magee R A. Worthwhile Investment: Universal Newborn Screening. Albany Government Law Review, March 2, 2009.

17. Illinois Register, Newborn metabolic Screening and Treatment Code, 77 Ill. Adm. Code 661 (revised), effective January 2010.

18. Therrell BL, Williams D, Johnson K, Lloyd-Puryear MA, Mann MY, Ramos LR. Financing newborn screening: sources, issues, and future considerations. J Public Health
Management \& Practice 2007;13:20713.

19. Johnson K, Lloyd-Puryear MA, Mann MY, Ramos LR, Therrell BL. Financing State Newborn Screening Programs: Sources and Uses of Funds. Pediatrics 2006; 117: 270-279.

20. W.K. Kellogg Foundation. Logic Model Development Guide, rev January 2004.

21. National Comprehensive Cancer Control Program Logic Model with CCC Priorities (as revised from), Given, L.S., Black, B., Lowry, G. et al. Collaborating to Conquer Cancer: A Comprehensive Approach to Cancer Control. Cancer Causes and Control (2005) 16 (Suppl. I): 3-14. doi:10.1007/s10552-005-0499-8

22. MCH Priority \# 3 Developmental Screening - MCH State-level Logic Model: Improve Developmental and Social Emotional Screening and Referral Rates of All Children Birth to Five.

https://www.colorado.gov/pacific/sites/ default/files/LPH_MCH_ABCD_Local _Logic-Model.pdf accessed September 15, 2016. 
Medical Research Archives, Vol. 4, Issue 6, October 2016

Facilitators and barriers to expansion of newborn screening programs in the 21 st century

23. Kemper AR, Green NS, Calogne N, et al. Decision-making process for conditions nominated to the Recommended Uniform Screening Panel: statement of the US Department of Health and Human Services
Secretary's Advisory Committee on Heritable Disorders in Newborns and Children. Genetics in Medicine. Advance online publication 1 August 2013. doi:10.1038/gim.2013.98 
Medical Research Archives, Vol. 4, Issue 6, October 2016

Facilitators and barriers to expansion of newborn screening programs in the 21st century

Table 1. Logic Model for Expansion of Newborn Screening for Genetic and Metabolic Disorders

\begin{tabular}{|c|c|c|c|c|c|}
\hline Resources & Activities & Outputs & Outcomes & Impact & Recommendations \\
\hline Financial & $\begin{array}{l}\text { To have funds available to } \\
\text { support new equipment, } \\
\text { test kits/materials. } \\
\text { More working space } \\
\text { Short term and long term } \\
\text { planning }\end{array}$ & $\begin{array}{l}\text { - to test for lab-based } \\
\text { cut-off } \\
\text { - to conduct pilot } \\
\text { testing. } \\
\text { - to evaluate quality } \\
\text { control/quality } \\
\text { assurance }\end{array}$ & $\begin{array}{l}\text { - to provide baseline } \\
\text { cut-off for targeted } \\
\text { population } \\
\text { - to support the } \\
\text { expansion or optional } \\
\text { program } \\
\text { - to determine incidence }\end{array}$ & $\begin{array}{l}\text { - public health } \\
\text { department } \\
\text { resource allocation. }\end{array}$ & $\begin{array}{l}\text { A matrix that can help facilitate budget } \\
\text { impact planning for state-level support } \\
\text { and federal-level or private support. }\end{array}$ \\
\hline $\begin{array}{l}\text { Human } \\
\text { Capital }\end{array}$ & $\begin{array}{l}\text { To have sufficient number } \\
\text { of personnel for testing, } \\
\text { follow-up, and } \\
\text { management of care and } \\
\text { have culturally-appropriate } \\
\text { educational material }\end{array}$ & $\begin{array}{l}\text { - sufficient time to } \\
\text { process and analyze } \\
\text { positive and negatives } \\
\text { - secondary screen. }\end{array}$ & $\begin{array}{l}\text { - to have timely results' } \\
\text { notification } \\
\text { - to request resamples } \\
\text { - to follow-up }\end{array}$ & $\begin{array}{l}\text { - to prompt } \\
\text { treatment } \\
\text { - explore long-term } \\
\text { management }\end{array}$ & $\begin{array}{l}\text { A model to project the time and effort by } \\
\text { personnel (new hires or relocated } \\
\text { personnel) or an integrated model across } \\
\text { different program within states or across } \\
\text { states. }\end{array}$ \\
\hline Technical & $\begin{array}{l}\text { To purchase the equipment } \\
\text { and/or testing material }\end{array}$ & $\begin{array}{l}\text { - an instrument that is } \\
\text { efficient and minimizes } \\
\text { processing time. } \\
\text {-multiplex capability }\end{array}$ & $\begin{array}{l}\text {-to achieve systematic } \\
\text { processing } \\
\text {-reduce human error. }\end{array}$ & $\begin{array}{l}\text {-to have a process } \\
\text { that is repeatable } \\
\text { and reliable. }\end{array}$ & $\begin{array}{l}\text { A criteria for purchase of new instrument } \\
\text { or testing materials. }\end{array}$ \\
\hline Policy & $\begin{array}{l}\text { IRB review } \\
\text { Support of political } \\
\text { sponsor } \\
\text { Support of stakeholders }\end{array}$ & $\begin{array}{l}\text {-to introduce legislation } \\
\text { or administrative rules } \\
\text { changes }\end{array}$ & $\begin{array}{l}\text {-to provide legal } \\
\text { authority for screening } \\
\text { activities }\end{array}$ & $\begin{array}{l}\text {-to provide for } \\
\text { eventual "standard } \\
\text { of care" }\end{array}$ & $\begin{array}{l}\text { Outcome of Success Analysis such as the } \\
\text { (SWOT analysis) }\end{array}$ \\
\hline
\end{tabular}


Medical Research Archives, Vol. 4, Issue 6, October 2016

Facilitators and barriers to expansion of newborn screening programs in the 21 st century

Table 2. Resources for Screening

\begin{tabular}{|c|c|c|c|c|}
\hline \multirow[t]{2}{*}{ Resources } & \multirow[t]{2}{*}{ Type } & \multicolumn{3}{|c|}{ Available? } \\
\hline & & Yes & No & N/A \\
\hline $\begin{array}{l}\text { 1. Is the laboratory facility currently equipped with the } \\
\text { infrastructure, technology, equipment and materials to add a } \\
\text { 'new screening test'? }\end{array}$ & Technical & & & \\
\hline $\begin{array}{l}\text { 2. Are the quantity (i.e., Is the supply chain available?) and } \\
\text { quality of laboratory materials adequate to add a 'new } \\
\text { screening test'? }\end{array}$ & Technical & & & \\
\hline $\begin{array}{l}\text { 3. Are the reporting algorithm and quality assurance plan } \\
\text { established for the 'new screening test'? }\end{array}$ & Technical & & & \\
\hline $\begin{array}{l}\text { 4. Are skilled laboratory analysts available to add a "new } \\
\text { screening test'? }\end{array}$ & $\begin{array}{l}\text { Human Capital and } \\
\text { Financial }\end{array}$ & & & \\
\hline $\begin{array}{l}\text { 5. Is adequate laboratory physical space available to add a } \\
\text { "new screening test'? }\end{array}$ & Financial & & & \\
\hline $\begin{array}{l}\text { 6. Are the financial costs associated with the additional } \\
\text { screening test identified and encumbered to ensure continuity } \\
\text { of the "new screening test'? }\end{array}$ & Financial & & & \\
\hline
\end{tabular}


Medical Research Archives, Vol. 4, Issue 6, October 2016

Facilitators and barriers to expansion of newborn screening programs in the 21 st century

Table 3. Resources for post-Screening Follow-up

\begin{tabular}{lll}
\hline Resources & Type & $\begin{array}{c}\text { Available? } \\
\text { No N/A }\end{array}$ \\
\hline $\begin{array}{l}\text { 1. Can the current follow-up system manage additional } \\
\text { 'reported positive cases'? }\end{array}$ & Policy \\
$\begin{array}{l}\text { 2. For new disorders, is additional expertise needed for the } \\
\text { personnel in follow-up? }\end{array}$ & Human Capital and \\
$\begin{array}{l}\text { 3. Can the current screening and follow-up infrastructure } \\
\text { support confirmatory testing/retesting? }\end{array}$ & Technical, Human \\
$\begin{array}{l}\text { 4. Has the algorithm for referral of 'reported positive cases' } \\
\text { been established? }\end{array}$ & Policy \\
$\begin{array}{l}\text { 5. Are there current medical specialists for diagnostic testing } \\
\text { and for clinical case work-up of 'reported positive cases'? }\end{array}$ & Human Capital and \\
$\begin{array}{l}\text { 7. What are the procedure in place to handle false positive } \\
\text { medical specialists? }\end{array}$ & Policy \\
\hline
\end{tabular}


Medical Research Archives, Vol. 4, Issue 6, October 2016

Facilitators and barriers to expansion of newborn screening programs in the 21 st century

Table 4. Resource for Medical Management:

\begin{tabular}{|c|c|c|c|c|}
\hline \multirow[t]{2}{*}{ Resources } & \multirow[t]{2}{*}{ Type } & \multicolumn{3}{|c|}{ Available? } \\
\hline & & Yes & No & N/A \\
\hline $\begin{array}{l}\text { 1. Is timely high specificity and sensitivity diagnostic } \\
\text { testing available? }\end{array}$ & Technical & & & \\
\hline $\begin{array}{l}\text { 2. Has the cost of the diagnostic testing and its impact on } \\
\text { program management been established? }\end{array}$ & Financial and Policy & & & \\
\hline $\begin{array}{l}\text { 3. Are/Should resources be available to accommodate } \\
\text { multi-tier or supplemental testing, such as travel to other } \\
\text { states' specialists for evaluation and care? }\end{array}$ & Financial and Policy & & & \\
\hline $\begin{array}{l}\text { 4. Are the physicians ready to handle to the additional } \\
\text { medical cases of true positive and possibly "mild cases"? }\end{array}$ & Human Capital & & & \\
\hline $\begin{array}{l}\text { 5. Is support for families with affected cases available, } \\
\text { either in-house, outsourced or via a telemedicine platform? } \\
\text { (e.g., genetic counseling) }\end{array}$ & Human Capital & & & \\
\hline $\begin{array}{l}\text { 6. What is the position of the program in atypical cases } \\
\text { where treatment is unavailable or treatment is of high cost } \\
\text { or is considered experimental? }\end{array}$ & Policy & & & \\
\hline
\end{tabular}


Medical Research Archives, Vol. 4, Issue 6, October 2016

Facilitators and barriers to expansion of newborn screening programs in the 21 st century

Table 5. Resources for Treatment

\begin{tabular}{lll}
\hline Resources & Type & $\begin{array}{c}\text { Available? } \\
\text { Yes }\end{array}$ \\
\hline $\begin{array}{l}\text { 1. Are effective treatment costs covered by health insurance } \\
\text { or other third-party payers? }\end{array}$ & Financial and Policy \\
$\begin{array}{l}\text { 2. Has the duration of treatment been established? } \\
\begin{array}{l}\text { 3. Are public funds available to support treatment based on } \\
\text { the standard of care? }\end{array}\end{array}$ \\
$\begin{array}{l}\text { 4. Will the treatment regimen affect parents' ability to } \\
\text { maintain employment? }\end{array}$ & Financial and Policy \\
\hline
\end{tabular}


Figure 1. "Generic" decision schematic for NBS Rules' change process

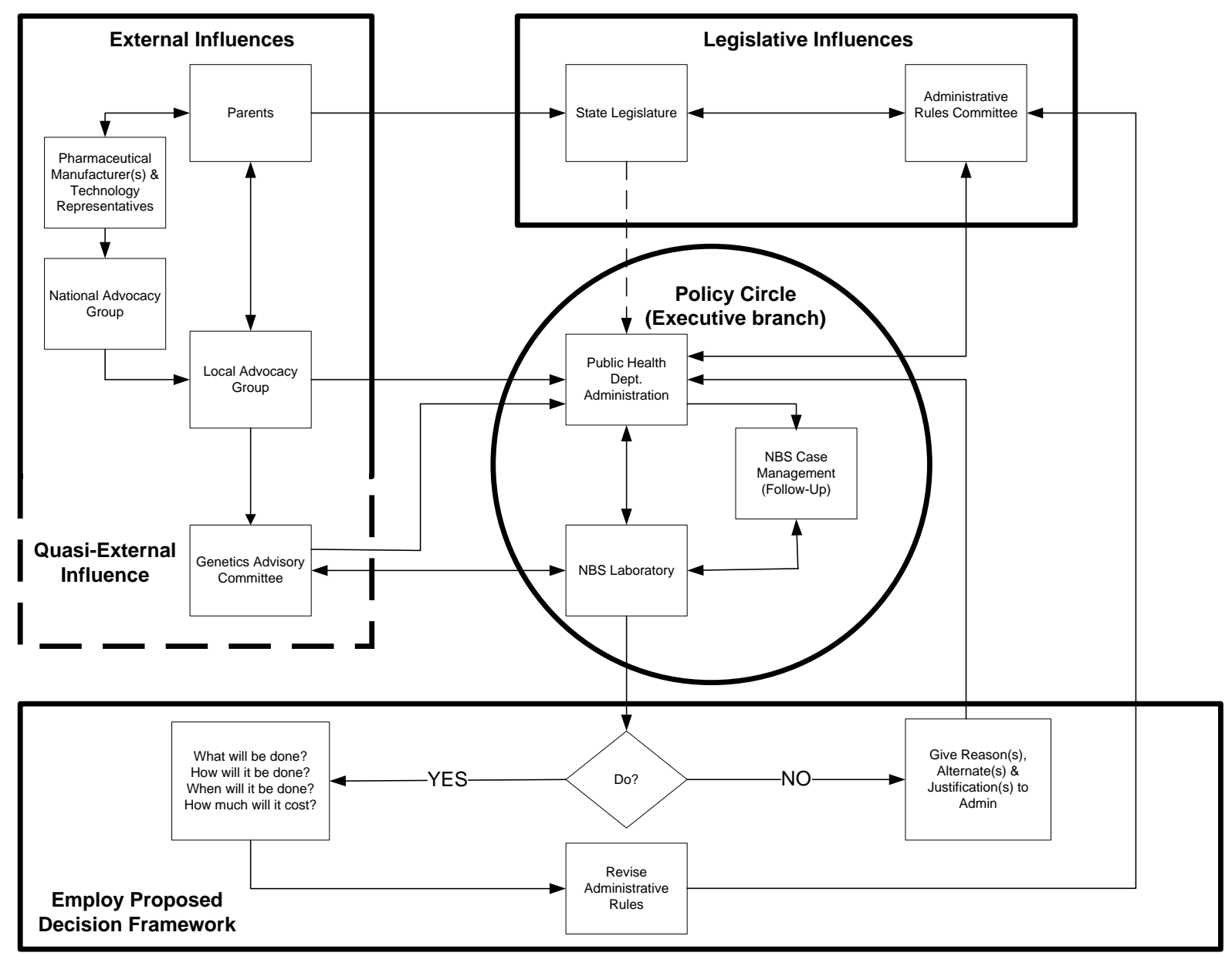

Figure 1 provides a schematic representing the complex relationships and interaction among stakeholders and the newborn screening system. 